\title{
OCCUPATION AS SOCIAL PART OF THE PEOPLE'S HEALTH
}

\author{
Ivanna Deka ${ }^{l}$ \\ Lviv Polytechnic National University, Lviv, Ukraine \\ ${ }^{1} \mathrm{Ph}$.D. Department of Sociology and Social Work, Associate member of Ukrainian Society of \\ Occupational Therapy
}

Background: Development of new profession in Ukraine requires deep analysis and learning of all the specifications of occupational therapy. Another important thing is the theoretical and methodological foundations of ergotherapy as a sphere of professional activity and vocational training, as well as the scientific and practical experience of preparing future occupational therapists in other countries. Occupational activity is the basis for client's involvement in everyday life. It has social, spiritual, physical and psychological significance, which is completely in line with the biopsycho-socio-spiritual model of human health.

Purpose: Study occupation in detail and demonstrate their social significance and impact on human health and well-being.

Methods: Theoretical research methods were used for a detailed analysis of occupation and to summarize the results.

Results: The results of a theoretical analysis of scientific sources have highlighted nine occupation that help the client live a fulfilling life. Each of them has many more components and opportunities for being occupied. Moreover, all the occupation depend on other factors: client factors, performance skills, performance patterns, context and environment, training requirements.

Conclusion: Occupation is focused on the client's needs, it is empowered with human values. Occupational participation has got social importance and elaborates human health and well-being.

Key words: occupation, occupational therapy, health.

Нещодавно в українському Класифікаторі професій з'явилася нова сфера діяльності «ерготерапія» (англ. Occupational Therapy). Ерготерапія - це первинна реабілітаційна професія у сфері охорони здоров'я, соціальних послуг та освіти, яка допомагає людям усіх вікових категорій (ГО «Українське товариство ерготерапевтів» [УТЕТ]). Клієнтами ерготерапевтів $\epsilon$ люди, які внаслідок фізичних, розумових, сенсорних, психоемоційних або соціальних проблем не можуть брати повноцінну участь у повсякденному житті. Основним засобом терапевтичного впливу ерготерапевта є заняттєва активність (заняття) - цілеспрямована діяльність у сфері самообслуговування, дозвілля та продуктивної діяльності (роботи), яку ерготерапевт обирає, адаптує і використовує відповідно до індивідуальних особистісних потреб, вподобань та функціональних можливостей клієнта та 3 урахуванням факторів середовища його життєдіяльності (УТЕТ).

Заняттєва активність включає в себе: активність повсякденного життя, інструментальну активність повсякденного життя, продуктивну діяльність (роботу), дозвілля і гру, освіту, відпочинок і сон, соціальну активність. Розглянемо детальніше кожну із них.

Активність повсякденного життя, тобто діяльність, орієнтовану на турботу про власне тіло, що є основою життя в соціальному світі та дозволяє елементарне виживання і благополуччя людини. Сюди відносяться купання, приймання душу; контроль дефекації і сечового міхура (за необхідності з використанням додаткового обладнання); вибір одягу, який відповідає часу доби та погоді; вміння приймати їжу; функціональна мобільність - переміщення з одного місця в інше при виконанні повсякденної діяльності, що включає використання і очищення засобів особистої гігієни (слухових апаратів, окулярів та ін.); особиста гігієна та догляд (використання бритви, пінцета, догляд за нігтями, вухами та ін.); сексуальна активність - це участь у діяльності, яка призводить до сексуального задоволення; туалетна гігієна (Roley, 2007).

Починаючи з раннього віку, необхідно налагоджувати процес прийому їжі, купання, одягання дітей з особливими потребами, якщо в цьому виникає необхідність. При порушеннях моторики навички самостійного обслуговування виробляються значно пізніше, іноді їх вироблення є зовсім не можливим. Тому багато зусиль зосереджується на адаптації до певних 
дій, як, наприклад у випадку, коли неможливо захопити одяг рукою, навчання «хитрих» рухів для одягання чи роздягання, заміни петель на гачки та липучки; створення допоміжних пристосувань: підвищеної накладки на унітаз та поручнів для допомоги під час сідання і вставання, спеціальних пристосувань до зубної щітки тощо. Фахівець супроводжує клієнта в усіх ранкових і вечірніх процедурах, допомагає спростити і налагодити проблемні дії, які звичайні люди виконують механічно, навіть не задумуючись. Індивідуальні відмінності полягають у тому, як саме клієнти розглядають свою занятість, а це відповідно відбивається на складності і багатовимірності професії «заняттєва терапія». Занятість класифікується в залежності від потреб та інтересів клієнта, точки зору цьього клієнта. Важливим $є$ також те, яким чином клієнти взаємодіють між собою та в заняттєвих активностях, що з часом може змінюватися. Обсяг і характер взаємодії так само важливі як і сама взаємодія;

Інструментальна активність повсякденного життя - заходи для підтримки повсякденного життя в сім'ї та суспільстві, які часто вимагають більш складної взаємодії, ніж самообслуговування. Сюди відносяться догляд за іншими (вибір помічника та контроль за ним); догляд за домашніми тваринами; догляд за дітьми; комунікативні вміння (використання телефону, комп'ютера, друкарської машинки та ін.); суспільна мобільність (наприклад здатність пересуватися у громадському транспорті); фінансовий менеджмент як здатність використовувати бюджетні ресурси в плануванні короткострокових та довгострокових цілей; охорона здоров'я (керування та вибір процедур для підтримки та зміцнення здоров'я, забезпечення хорошого самопочуття); догляд за домом (підтримка домашнього господарства, двору, саду, ремонт майна); приготування їжі (очищення їжі, вибір збалансованого харчування, прибирання посуду після прийому їжі); духовність (дотримання релігійних звичаїв); безпека та аварійне обслуговування (визначення небезпечних ситуацій для зменшення загрози для життя); купівля товарів (підготовка списку покупок, транспортування та оплата товарів) (Anthony, Brinson \& Brownrigg, 2002).

Продуктивна діяльність (робота) включає в себе заходи, необхідні для участі у вигідній занятості, або волонтерська діяльність. Сюди відносяться інтереси занятості (вибір можливостей роботи, враховуючи інтереси та уподобання); пошук роботи і працевлаштування (виявлення робочих місць, заповнення і подання до розгляду резюме, співбесіда тощо); продуктивна робота (оволодіння трудовими навичками, виконання функцій, дотримання норм і процедур роботи, завершення роботи); підготовка до пенсії (визначення здібностей та відповідних занять для їх реалізації); пошук можливостей для волонтерської діяльності виявлення неоплачуваної роботи задля реалізації навичок, інтересу і прагнення до залучення та приналежності; волонтерська участь (виконання неоплачуваної діяльності в інтересах організаціï) (Kielhofner, 2008).

Дозвілля - це необов'язкова діяльність, що виконується у вільний час і не вимагає обов'язкового виконання. Сюди відносять вільне дозвілля - виявлення інтересів, навичок, можливостей клієнта; участь у дозвіллі - планування та учать у визначених різновидах дозвілля, підтримку балансу в інших областях занятості та за необхідності використання спеціального обладнання (Anthony et al., 2002).

Гра - будь-яка спонтанна чи організована діяльність, яка забезпечує задоволення та розваги. Сюди відносять дослідження гри - визначення відповідних ігрових заходів, які включають гру на практиці, ролі, правила гри, цікаві для клієнта; участь у грі - залучення до гри, підтримка взаємодії з іншими гравцями, використання різноманітних предметів у грі та ін.;

Освіта включає заходи необхідні для навчання та участі у взаємодії з навколишнім середовищем. Сюди відносяться формальна освітня діяльність (читання, математика та ін.); задоволення особистих освітніх потреб (методи отримання інформації, навички тощо); неформальна приватна освіта (участь у програмах і заходах, які забезпечують навчання в певних областях, які викликають інтерес) (World Federation of Occupational Therapy [WFOT]).

Пристосування дітей до навчання в школі та пристосування шкільного середовища до потреб учнів $з$ особливими потребами - це завдання ерготерапії. Одним із них $є$ облаштування фізичного середовища школи (зокрема класної кімнати) - підбір та адаптація меблів та ін. 
Пристосування до інтеграції в шкільне середовище має відбуватися на особистому рівні, на рівні колективу школи та шкільних програм (Klinger, 2005). Очевидно, що крім ерготерапії, необхідні й інші, так звані супутні служби: аудіологія, консультаційні, психологічні, медичні та рекреаційні служби, раннє обстеження та визначення особливих потреб, тренінги для батьків, фізична терапія, допомога соціального працівника, логопеда, спеціальне транспортування;

Відпочинок $i$ сон включають діяльність, пов'язану з відновленням сил організму та сном, підтримку здоров'я, що забезпечує активну участь в інших заняттєвих активностях. Ерготерапія інтерпретує поняття «відпочинок» як «спокійні та невимушені дії, які переривають фізичну і розумову активність та призводять до розслабленого стану» (В. Нуріт, А. Мічел, 2003). Відпочинок також виявляє необхідність розслабитися, знизити фізичну, психічну або громадську активність і залучитися до методів відновлення енергії та спокою. Сон відноситься до відпочинку і включає в себе декілька етапів, що їх враховують ерготерапевти:

1) підготовка до сну - залучення до систем соціального середовища, які готують особу до комфортного стану спокою (наприклад пестощі; переодягання; читання книги або прослуховування музики, щоб заснути; побажання гарної ночі іншим; медитація або молитва); визначення тривалості часу, необхідного для сну або конкретного часу, коли необхідно прокидатися. Це все визначається згідно з особистими і культурними нормами та цінностями людини;

2) підготовка фізичного середовища до сну - вміння стелити ліжко або інше місце для сну; забезпечення потрібного рівня тепла/холоду; налаштування будильника; забезпечення безпеки у будинку, закриття дверей на замок або зачинення вікна чи фіранки; вимкнення електротехніки або світла;

3) участь у сні/сон - турбота про такі особисті потреби під час сну, як припинення діяльності, щоб забезпечити час сну, дрімання, мріяння, підтримання стану сну без порушень, турбота про доступність туалету; взаємодія з дітьми, партнером, чоловіком/дружиною, забезпечення нічного догляду, а також контроль за комфортом і безпекою інших членів сім’'і під час сну (American Journal of Occupational Therapy, 2002).

Соціальна активність - організовані моделі діяльності, які є характерними та очікуються від індивіда в конкретній ситуації всередині соціальної системи. Для реалізації соціальної участі важливим $є$ врахування таких понять, як

- суспільство - передбачена участь у діяльності, що спричиняє успішну взаємодію на рівні громади, тобто району, організації, місця роботи чи навчання;

- сім'я - передбачена участь у «діяльності, результатом якої є успішна взаємодія у здійсненні необхідних або бажаних сімейних ролей»;

- друг/партнер - передбачена участь у діяльності на різних рівнях близькості, включно 3 бажаною для особи сексуальною участю (American Journal of Occupational Therapy, 2008).

Можливість заняттєвої участі має важливе психологічне, духовне та соціальне значення для клієнта. Ерготерапія передбачає клієнт орієнтований підхід роботи із людиною, сім'єю, громадою. Тобто, кожна заняттєва активність наповнена змістом, цінностями та потребами конкретного клієнта. Рівень заняттєвої участі людини залежить також від факторів клієнта, виконавчих умінь і навичок, виконавчих моделей, контексту і середовища, вимог до заняття. Кінцевий результат має сенс для людини, для її благополуччя, життя та здоров'я. Заняттєва активність додає сил, впевненості та наснаги до її виконання. Це мотивація жити повноцінним життям, приймати активну соціальну участь, бути продуктивним та корисним для оточення.

\section{Список використаних джерел}

ГО «Українське товариство ерготерапевтів». Позиційна заява. Визначення ерготерапії, 2018p. $-\mathrm{c} .2$

Anthony, P., Brinson, C. M., Brownrigg, S., Clark, G. F., Desmarais, S. M., Sellers, J., ... \& Deborah Lieberman, M. H. S. A.(2002) Occupational therapy practice framework Domain and Process. Occupational Therapy Practice, $-83 \mathrm{p}$.

Kielhofner, G. (2008). Model of Human Occupation: Theory and Application. United State of America, $-565 \mathrm{p}$. 
Klinger, L. (2005). Occupational adaptation: Perspectives of people with traumatic brain injury. Journal of Occupational Science, 12(1), 9-16.

Occupational Therapy Practice Framework: Domain and Process (2002). American Journal of Occupational Therapy, 56, 609-639.

Occupational Therapy Practice Framework: Domain and Process, $2^{\text {nd }}$ Edition (2008). American Journal of Occupational Therapy, 62, 625-683.

Roley, S. S., et al. (2007). Occupational therapy practice framework: domain \& practice. The American journal of occupational therapy: official publication of the American Occupational Therapy Association, 62(6), 625-683.

World Federation of Occupational Therapists (2017). Definitions of occupational therapy from member organizations. Retrieved from http://www.wfot.org/ResourceCentre/tabid/132/did/827/Default.aspx

\section{References}

Public organization "Ukrainian Society of Occupational Therapists". Position statement. Definition of occupational therapy, 2018p. - c.2

Anthony, P., Brinson, C. M., Brownrigg, S., Clark, G. F., Desmarais, S. M., Sellers, J., ... \& Deborah Lieberman, M. H. S. A.(2002) Occupational therapy practice framework Domain and Process. Occupational Therapy Practice, $-83 \mathrm{p}$.

Kielhofner, G. (2008). Model of Human Occupation: Theory and Application. United State of America, $-565 \mathrm{p}$.

Klinger, L. (2005). Occupational adaptation: Perspectives of people with traumatic brain injury. Journal of Occupational Science, 12(1), 9-16.

Occupational Therapy Practice Framework: Domain and Process (2002). American Journal of Occupational Therapy, 56, 609-639.

Occupational Therapy Practice Framework: Domain and Process, $2^{\text {nd }}$ Edition (2008). American Journal of Occupational Therapy, 62, 625-683.

Roley, S. S., et al. (2007). Occupational therapy practice framework: domain \& practice. The American journal of occupational therapy: official publication of the American Occupational Therapy Association, 62(6), 625-683.

World Federation of Occupational Therapists (2017). Definitions of occupational therapy from member organizations. Retrieved from http://www.wfot.org/ResourceCentre/tabid/132/did/827/Default.aspx 